\title{
Bridging the gap between sustainability, the regulatory, and the recycling of construction and demolition waste in the UAE, with specific reference to the Emirate of Sharjah
}

\author{
Marta Bialko, ${ }^{1, *}$ \\ ${ }^{1}$ University of Sharjah, Architectural Engineering Department, Sharjah, UAE
}

\begin{abstract}
Waste management is currently an inherent part of sustainable construction and, thus, sustainable development. Construction and demolition waste is an issue continuously intensifying in every country. The primary object of this paper is to present issues associated with a gap between sustainable building regulations in the United Arab Emirates, and the recycling facilities such as the Bee'ah facility in Sharjah. Existing construction and demolition waste management has been investigated in terms of available literature as well as for construction sites and the precast concrete factory located in Sharjah.
\end{abstract}

\section{Introduction}

The objective of the research is to review the sustainability dimension of building regulations in the United Arab Emirates (UAE) with respect to current practices implemented by contractors to manage construction and demolition (C\&D) waste, along with the recycling process as the last step of sustainable waste management. The findings are based on interviews with contractors, and project managers as well as a literature review. The UAE legislation was assessed for the three emirates of Abu Dhabi, Dubai, and Sharjah each and compared with other regulatory bodies.

\subsection{Definition of Sustainable development}

As we know, the planet has limited natural resources for energy and materials and this is why it is important to conduct urban development while protecting the environment so future generations can use those natural resources. This is the Brundtland Report [1] definition of sustainability that says: 'Sustainable development is development that meets the needs of the present without compromising the ability of future generations to meet their own needs'. Sustainable development has undergone numerous transformations since the first principles were adopted by the United Nations at a conference in Stockholm in 1972, and when the last amendments were made on 25-27 September 2015 in New York as

\footnotetext{
*Corresponding author: mbialko@sharjah.ac.ae
} 
the document "Transforming our world: the 2030 Agenda for Sustainable Development" (Agenda 2030). This document contains 17 goals relating sustainable development to the society, the environment, and the economy [2]. Table 1 shows selected goals of sustainable development in Agenda 2030 as they relate to sustainable development in the construction industry.

Table 1. Selected goals of the sustainable development in Agenda 2030, as they relate to sustainable development in the construction industry. [2]

\begin{tabular}{|l|l|}
\hline Goal 3. & Ensure healthy lives and promote well-being for all at all ages \\
\hline Goal 6. & $\begin{array}{l}\text { Ensure availability and sustainable management of water and } \\
\text { sanitation for all }\end{array}$ \\
\hline Goal 7. & $\begin{array}{l}\text { Ensure access to affordable, reliable, sustainable and modern } \\
\text { energy for all }\end{array}$ \\
\hline Goal 8. & $\begin{array}{l}\text { Promote sustained, inclusive and sustainable economic growth, } \\
\text { full and productive employment and decent work for all }\end{array}$ \\
\hline Goal 9. & $\begin{array}{l}\text { Build resilient infrastructure, promote inclusive and sustainable } \\
\text { industrialization and foster innovation }\end{array}$ \\
\hline Goal 11. & $\begin{array}{l}\text { Make cities and human settlements inclusive, safe, resilient and } \\
\text { sustainable }\end{array}$ \\
\hline Goal 12. & Ensure sustainable consumption and production patterns \\
\hline Goal 13. & Take urgent action to combat climate change and its impacts \\
\hline Goal 15. & $\begin{array}{l}\text { Protect, restore and promote sustainable use of terrestrial } \\
\text { ecosystems, sustainably manage forests, combat desertification, } \\
\text { and halt and reverse land degradation and halt biodiversity loss }\end{array}$ \\
\hline
\end{tabular}

Sustainable development has been already implemented into building regulations in many countries around the world. It is included in the Regulation (EU) No 305/2011 of the European Parliament and of the Council of the European Union of 9 March 2011 [3] which introduced sustainable construction as a new, seventh basic requirement: "Sustainable use of natural resources. The construction works must be designed, built and demolished in such a way that the use of natural resources is sustainable and in particular ensure the following:

a) reuse or recyclability of the construction works, their materials and parts after demolition;

b) durability of the construction works;

c) use of environmentally compatible raw and secondary materials in the construction works."

The Directive 2008/98/EC of the European Parliament and of the Council [4] on waste sets a waste management hierarchy with prevention, reuse, recycle and recover as the most preferable since they produce the least waste, to disposal as the least preferable.

Adapting a building to the principles of sustainable development requires much effort, change, and wise planning over the full life cycle of a building. The principles of sustainable development in the construction industry pay special attention to the use of building materials that can be reused or recycled.

\subsection{Sustainable regulations in the UAE}

Many countries around the world have their own systems and standards to protect the environment and regulate work in the construction industry. The most popular standards used throughout the world are Leadership in Energy and Environmental Design (LEED) and BRE Environmental Assessment Method (BREEAM). The oldest system is BREEAM 
that has been created in the UK in 1990 [5] and the LEED system generated in the United States in 1998 [6]. The UAE has only relatively recently joined the list of countries with their own system with the Emirate of Abu Dhabi establishing Estidama in 2010 [7] and the Emirate of Dubai creating the 'Green Building Regulations and Specifications in the Emirate of Dubai' in 2011 that has been mandatory for all new buildings since 2014 [8].

LEED, BREEAM, Estidama and the Green Building Regulations and Specifications in the Emirate of Dubai all guide and assess buildings according to similar principles based on goals of the sustainable development written in Agenda 2030 (Table 2).

Table 2. Comparison of systems BREEAM, LEED, Estidama and the Green Building Regulations and Specifications in the Emirate of Dubai with goals of the sustainable development written in Agenda 2030.

\begin{tabular}{|c|c|c|c|c|}
\hline $\begin{array}{l}\text { Goals of the } \\
\text { sustainable } \\
\text { development, } \\
\text { Agenda } 2030 \\
\text { [2] }\end{array}$ & $\begin{array}{l}\text { BREEAM } \\
{[5]}\end{array}$ & LEED [6] & Estidama [7] & $\begin{array}{l}\text { Green Building } \\
\text { Regulations and } \\
\text { Specifications in } \\
\text { the Emirate of } \\
\text { Dubai [8] }\end{array}$ \\
\hline Goal 3 and 11 & $\begin{array}{l}\text { Health and } \\
\text { Wellbeing }\end{array}$ & $\begin{array}{l}\text { Indoor } \\
\text { Environmental } \\
\text { Quality }\end{array}$ & $\begin{array}{l}\text { Livable } \\
\text { Buildings }\end{array}$ & Building Vitality \\
\hline Goal 6 & Water & $\begin{array}{l}\text { Water } \\
\text { Efficiency }\end{array}$ & $\begin{array}{l}\text { Precious } \\
\text { Water }\end{array}$ & $\begin{array}{l}\text { Resource } \\
\text { Effectiveness: } \\
\text { Water }\end{array}$ \\
\hline Goal 7 & Energy & $\begin{array}{l}\text { Energy and } \\
\text { Atmosphere }\end{array}$ & $\begin{array}{l}\text { Resourceful } \\
\text { Energy }\end{array}$ & $\begin{array}{l}\text { Resource } \\
\text { Effectiveness: } \\
\text { Energy }\end{array}$ \\
\hline Goal 8 & Management & $\begin{array}{l}\text { Integrative } \\
\text { Process }\end{array}$ & $\begin{array}{l}\text { Integrative } \\
\text { Development } \\
\text { Process }\end{array}$ & 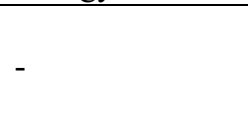 \\
\hline Goal 9 & Transport & $\begin{array}{l}\text { Location and } \\
\text { Transportation }\end{array}$ & $\begin{array}{l}\text { Livable } \\
\text { Buildings } \\
\text { (Outdoors) }\end{array}$ & $\begin{array}{l}\text { Ecology \& } \\
\text { Planning }\end{array}$ \\
\hline & Innovation & Innovation & $\begin{array}{l}\text { Innovating } \\
\text { Practice }\end{array}$ & - \\
\hline Goal 12 & $\begin{array}{l}\text { Materials and } \\
\text { Waste }\end{array}$ & $\begin{array}{l}\text { Materials and } \\
\text { Resources }\end{array}$ & $\begin{array}{l}\text { Stewarding } \\
\text { Materials }\end{array}$ & $\begin{array}{l}\text { Resource } \\
\text { Effectiveness: } \\
\text { Materials and } \\
\text { Waste }\end{array}$ \\
\hline Goal 13 & Pollution & $\begin{array}{l}\text { Sustainable } \\
\text { Sites }\end{array}$ & \multirow{2}{*}{$\begin{array}{l}\text { Natural } \\
\text { Systems }\end{array}$} & \multirow{2}{*}{$\begin{array}{l}\text { Ecology \& } \\
\text { Planning }\end{array}$} \\
\hline Goal 15 & $\begin{array}{l}\text { Land Use } \\
\text { and Ecology }\end{array}$ & $\begin{array}{l}\text { Regional } \\
\text { Priority }\end{array}$ & & \\
\hline
\end{tabular}

As shown in Table 2, all statements in BREEAM, LEED and Estidama fully cover the sustainable development objectives of Agenda 2030 but the Green Building Regulations and Specifications in the Emirate of Dubai needs to improve in two aspects in order to do the same. The objectives of sustainable development as established by the organization of the United Nations generally dictate the law protecting the environment and the principles of ecological systems in the UAE. It also indicates how sustainability has been incorporated into UAE legislation. 


\subsection{Definition of construction and demolition (C\&D) waste}

C\&D waste can be defined in many ways, one of which is "the waste material produced in the process of production, construction, renovation, or demolition of structures" [9]. As per the Building Research Establishment (BRE) (1978) it can be also defined as "the difference between materials ordered and those placed for fixing on building projects". A more detailed definition was provided by A. Dania [10] who said "construction and demolition waste is a complex waste stream, made up of a wide variety of materials which are in the form of building debris, rubble, earth, concrete, steel, timber, and mixed site clearance materials, arising from various construction activities including land excavation or formation, civil and building construction site, clearance, demolition activities, road-work, and building renovation." The definitions of C\&D waste can be a subject of a separate study.

\subsection{Classification of sources of C\&D waste in a full life cycle of a building}

Many studies have been conducted to specify sources of the C\&D waste throughout the entire life cycle of a building. The main four stages named by Ekanayake and Ofori [11, 12] are (1) design, (2) procurement, (3) handling of materials, and (4) operation. They confirmed that the maximum numbers of causes of waste are already created at the design stage [11]. A survey conducted by Saunders and Wynn (2004) also proved that wrong design is the main reason for excessive off-cuts and the production of waste [12]. Research by Bossink and Brouwers [13] and by Gavilan and Bernold [14] specified the six main causes of waste as design, procurement, material handling, operation, residual, and others. Lingard classified the four causes of [15], procurement, handling, operation, and a cultural cause that added a behavioural motive.

C\&D waste was also classified by amounts produced annually. Studies conducted in Kuwait [16] reveal that the main sources of C\&D waste are (in decreasing order from the most produced) "demolition of old buildings, leftovers from new construction, building repair and maintenance, and manufacturing debris". The U.S. Department of Energy [17] waste generation statistics specify $19.5 \mathrm{~kg} / \mathrm{m} 2$ as a minimum for new construction and 757 $\mathrm{kg} / \mathrm{m} 2$ as a minimum for building demolition. In summary, C\&D waste is produced over the full life cycle of a building, beginning at the design stage and continuing throughout construction and use of a building (e.g. renovations and repairs), but the largest amount of waste is generated during demolition.

\section{Case studies}

Three case studies including two construction sites at different stages and with different functions, and one concrete precast factory were visited to study the general production of C\&D waste and sustainable approaches. Conclusions were compared with the literature findings.

\subsection{C\&D waste generated in the production of construction materials \& components - case study A}

The C\&D waste generated during the production of construction materials has been studied in general using the example of the Sharjah factory Emirates Stone that produces concrete components, glass reinforced concrete components (GRC), and glass reinforced plastic (GRP) components. The wide range of items produced includes internal walls, external walls with insulation, external elevation panels, foundations, and concrete columns, slabs, 
and fences. It also makes many types of GRC and GRP decorative and free-standing elements. All are used in all types of buildings up to eight floors in height. External walls have from 20 to $40 \mathrm{~mm}$ of Styrofoam insulation and slabs are produced in widths of $1200 \mathrm{~mm}$ and lengths of 120 meters and cut as per project requirements.

Elements with simple shapes such as foundations, columns, slabs, and unornamented walls are cast in steel moulds that can be used at least 100 times before being cleaned, repaired and polished ready for re-use. Ornamented walls are cast in wooden moulds that include rubber forms for the details. Wooden formwork made from MDF can be used from five to eight times.

C\&D waste was produced in the manufacture of components of all types. The following are the results of my own observations as well as interviews with factory representatives.

\subsubsection{Produced type of waste:}

- Wood - old wooden moulds are discarded along with the steel ones.

- Steel - two types of steel waste were observed:

- Steel from moulds - parts that are already worn out and cannot be renewed or reused are sent to a landfill at the factory.

○ Cut-offs from steel reinforcing bars is also directed to the factory landfill.

- Concrete and reinforced concrete - defective / broken during production, or old or worn-out components (e.g. walls, slabs, or fences) brought from construction sites are send to the factory landfill.

- Plastic - this type of waste is also placed together with other materials in the factory landfill.

- GRC and GRP - defective / broken during production, or old worn out components (e.g. decoration panels, ornaments, benches, or fountains) brought from construction sites are sent to the factory landfill.

\subsubsection{Conclusions}

As representatives of the precast factory admit, the waste is not segregated. The factory landfill contains different types of $\mathrm{C} \& \mathrm{D}$ waste stored along with general waste (e.g. packaging, soil, or even organic waste generated by employees). The factory produces large amounts of valuable $\mathrm{C} \& \mathrm{D}$ waste suitable for recycling (i.e. concrete, reinforced concrete, MDF, wood, and steel) and large amounts of non-recyclable waste (i.e. GRC and GRP). Due to the mixing of waste, many of these valuable materials are wasted in the landfill. Furthermore, the factory does not have a waste management plan and as representatives declare the waste is not collected regularly. In this case, the problem is a lack of a waste management plan and a lack of awareness of the impact of waste on the environment. Additionally, the management is unaware of the financial benefits that can result from C\&D waste management and recycling, that results in a lack of support from their side to train the staff. 


\subsection{C\&D waste generated during the process of construction - case study B and $C$}

Two different construction sites at various stages of completion and with different functions were chosen as examples of generating construction waste, and were visited. Both construction sites were for buildings of precast concrete components supplied by the factory described in case study A.

The first project (case study B) is a two-storey building that will be dormitories for the Medical College of the University of Sharjah (Sharjah, the UAE), where interior works were in progress. At the construction site, preliminary segregation of construction waste such as cardboard, aluminium, plastic pipes, or dirty metal waste was seen. However, the containers were small and clean recyclable waste (e.g. aluminium pipes) was mixed with dirty waste (e.g. metal covered in oil). A skip with various types of unsorted general waste e.g., plastic packaging, soil, and organic waste, that also contained recyclable materials such as cardboard, or wooden pallets was observed during site walks. A project manager admits that the same garbage truck irregularly collects both segregated and unsegregated waste. Only cardboard is collected separately in accordance with recycling factory requirements. According to the project manager, waste is segregated at the recycling plant (Bee'ah). This however is not the case since Bee'ah confirms that any recyclable waste mixed with prohibited waste is sent to landfill. Valuable materials are therefore still being wasted even though there is basic segregation of construction waste onsite. The reason is a lack of training of the staff and thus a lack of knowledge about the C\&D waste management plan. The main problem is a lack of environmental awareness.

The second project is the Arabic College Language Building (case study C) in Sharjah, the UAE that is single storey and was visited during an early construction stage where the foundations were finalized and the ground floor was being constructed. During this phase, very little construction waste was observed. According to a project manager, waste on the site is not segregated and there is no plan to. Furthermore, all concrete waste (i.e. defective or broken during construction or transport, concrete components) is send back to the precast factory. In this case the problem is more complex because there is no waste management plan and the project manager does not consider it as necessary to segregate waste. The waste management issue is passed back to the factory producing the precast concrete components. There is therefore a lack of environmental awareness and professional training. At the site, the improper storing of concrete elements that can damage them and generate more waste was also observed.

Table 3. The summary of the main causes of $C \& D$ waste observed during the study.

\begin{tabular}{|c|c|c|c|}
\hline & Case study A & Case study B & Case study $\mathrm{C}$ \\
\hline Type & Precast concrete factory & Residential & Educational \\
\hline Stage & Production & Finishing & Structure \\
\hline $\begin{array}{l}\text { Type of } \\
\text { C\&D waste }\end{array}$ & $\begin{array}{l}\text { - Wood after repeated } \\
\text { use } \\
\text { - Steel (after repeated } \\
\text { use and off-cuts) } \\
\text { - Concrete and } \\
\text { reinforced concrete } \\
\text { - Plastics } \\
\text { - GRC and GRP }\end{array}$ & $\begin{array}{l}\text { - packaging } \\
\text { (cardboard, and } \\
\text { wooden) } \\
\text { - aluminium cut-offs } \\
\text { - plastics } \\
\text { - dirty metal waste } \\
\text { - soil }\end{array}$ & $\begin{array}{l}\text { - wooden packaging } \\
\text { - precast concrete }\end{array}$ \\
\hline $\begin{array}{l}\text { Possible } \\
\text { causes }\end{array}$ & $\begin{array}{l}\text { - a lack of the waste } \\
\text { management plan } \\
\text { - a lack of awareness }\end{array}$ & $\begin{array}{l}\text { - a lack of the waste } \\
\text { management plan } \\
\text { - a lack of awareness }\end{array}$ & $\begin{array}{l}\text { - improper storing } \\
\text { - lack of a waste } \\
\text { management plan }\end{array}$ \\
\hline
\end{tabular}




\begin{tabular}{|l|l|l|l|}
\hline & $\begin{array}{l}\text { - a lack of } \\
\text { management's support } \\
\text { - a lack of training }\end{array}$ & - a lack of training & $\begin{array}{l}\text { - a lack of awareness } \\
\text { - a lack of training }\end{array}$ \\
\hline
\end{tabular}

Most of the causes including lack of C\&D waste management plan are connected to a lack of awareness and can be grouped under 'culture', according to Lingard [15]. Only improper storing can be categorized [15] as a handling issue. The study performed in Jordan [18] confirms that 'poor strategy for waste minimization' is one of the major reasons of material waste in construction, and lists it in a ranking of causes of wastage as fifth out of 25. Additionally, the same ranking lists 'wrong and lack of storage of materials' as fourth. Findings in the research done in the UAE [12], confirm that 'lack of workers' awareness' is the main cause of material wastage. This is a general issue in the UAE construction industry. Moreover, the same ranking [12] lists 'inappropriate storage' as sixth out of 13 .

\section{The required percentage of diverted C\&D waste from landfill as per selected international regulations}

In the recycling process waste materials are converted into new reusable materials and objects. A high percentage of recycled building materials depend on the type of material used originally, building technology, and the waste management. The required percentages of diverted C\&D waste from landfill are compared in Table 3 for BREEAM, LEED, Estidama and the Green Building Regulations and Specifications in the Emirate of Dubai. The comparison clearly shows that the respective requirements are similar to the each other and converge at around $70 \%$. However, the LEED and Estidama have the basic mandatory rates consecutively $50 \%$ and $30 \%$ where the non-standard requirements are $70 \%$ for both of them. The situation is slightly different for BREEAM which lists separate percentages for construction and demolition waste that range between $60 \%$ and $75 \%$.

The comparison of the requirements of the above standards shows that in the United States, Europe, and the UAE, the required percentages of diverted C\&D waste from landfill are very similar. This shows that since 2010 [12] the sustainable side of building regulations including C\&D waste management, in the UAE has improved and is continuing to do so. 
Table 4. The comparison of required percentage of diverted C\&D waste from landfill for BREEAM, LEED, Estidama and the Green Building Regulations and Specifications in the Emirate of Dubai.

\begin{tabular}{|c|c|c|c|}
\hline \multicolumn{4}{|c|}{$\begin{array}{l}\text { The required percentage of diverted C\&D waste from landfill as per international } \\
\text { standards. } *\end{array}$} \\
\hline $\begin{array}{l}\text { BREEAM [5] } \\
\% \text { - as shown below }\end{array}$ & $\begin{array}{l}\text { LEED [6] } \\
\% \text { by } \\
\text { volume or } \\
\text { weight }\end{array}$ & $\begin{array}{l}\text { Estidama [7] } \\
\% \text { by volume or } \\
\text { weight }\end{array}$ & $\begin{array}{l}\text { Green Building } \\
\text { Regulations and } \\
\text { Specifications in the } \\
\text { Emirate of Dubai }[8] \\
\% \text { by volume or weight }\end{array}$ \\
\hline $\begin{array}{l}\text { Construction waste: } \\
\text { - } \geq 60 \% \text { (by weight) } \\
\text { or } \geq 50 \% \text { (by volume) } \\
\text { ( } 1 \text { credit) } \\
\text { - } \geq 75 \text { (by weight) } \\
\text { or } \geq 65 \% \text { (by volume) } \\
\text { (Exemplary level, } 2 \\
\text { credits) } \\
\text { Demolition waste: } \\
\text { - } \geq 70 \% \text { (by weight) or } \\
\geq 60 \% \text { (by volume) (1 } \\
\text { credit) } \\
\text { - } \geq 75 \% \text { (by weight) or } \\
\geq 65 \% \text { (by volume) } \\
\text { (Exemplary level, } 2 \\
\text { credits) }\end{array}$ & $\begin{array}{l}50 \% \\
(1 \text { point }) \\
70 \% \\
(2 \text { points) }\end{array}$ & $\begin{array}{l}30 \% \text { (mandatory } \\
\text { credit) } \\
50 \% \text { ( } 1 \text { optional } \\
\text { credit point) } \\
70 \% \text { ( } 2 \text { optional } \\
\text { credit points) } * *\end{array}$ & Minimum $50 \%$ \\
\hline
\end{tabular}

* As per each listed in the table standards diverted C\&D waste from landfill must be recycled or reused.

** As per Estidama rating system, all new projects in Abu Dhabi (after 2010) must meet all mandatory credit requirements to obtain a 1 Pearl rating. To reach a higher Pearl rating, a project must meet all mandatory credit requirements along with optional credit points requirements [7].

\section{Recycling of C\&D waste in the UAE, with specific reference to the Emirate of Sharjah}

In the UAE, the most recent government statistics reveal that almost 26 million tonnes of waste were collected across the country in 2014 [19]. Statistics are not available for C\&D waste collected across all emirates as each emirate has different companies to collect waste and recycle it. Recycling factories in Abu Dhabi and Al Ain have C\&D waste capacity of approximately $1,825,000$ tons per emirate yearly [20]. This number is not related to C\&D waste collected in total but only to recycled bulk. As per a 2011 Dubai Municipality report $6,638,471$ tons of C\&D waste was generated for only Dubai, where the C\&D Recycling Facility can process approximately 1,635,200 tons annually [21].

In Sharjah, Bee'ah Construction \& Demolition Waste Recycling Facility processes more than 2,190,000 tons of C\&D waste per year. Bee'ah's Material Recovery Facility is the largest in the Middle East and the third largest in the world [22]. Tables 4 and 5 show C\&D waste (in tonnes) for the three waste types of C\&D (mineral), Mix C\&D, and Asphalt 
processed by Bee'ah, for 2015 and 2016. In Bee'ah the recovery rate of C\&D waste in 2015 is $97.8 \%$ and in 2016 (up to the end of April) is $98.1 \%$ [22].

Table 5. Tonnages received of each category of C\&D waste in 2015 and in 2016 up to end of April. (As per statistics provided by Bee'ah) [22]

\begin{tabular}{|l|l|l|}
\hline $\begin{array}{l}\text { Types of C\&D waste } \\
\text { material as per Bee'ah } \\
\text { categorization }\end{array}$ & 2015 & $\begin{array}{l}2016 \text { up to the end of } \\
\text { April* }\end{array}$ \\
\hline C\&D (mineral) & $135,789.74$ ton & $66,404.04$ ton \\
\hline Asphalt & $7,637.76$ ton & $3,090.81$ ton \\
\hline Mix C\&D & $39,261.02$ ton & $41,642.77$ ton \\
\hline Total & $182,688.52$ ton & $111,137.62$ ton \\
\hline
\end{tabular}

Bee'ah uses a combination of manual and mechanical sorting of waste to recover materials such as paper, mixed paper, cardboard, aluminum cans, steel cans, and many others. The same technique is used in the recycling of C\&D waste [22].

The full C\&D waste recycling process is shown in Fig. 1. General waste is given a first examination at the first inspection point by employees. If it is classified as C\&D waste it is sent to the main gate where the waste is weighted, a license is checked and a payment received. If the waste is prohibited because it includes gypsum, powder, marble, asbestos, green landscaping waste, sand with oil or it is sewage or hazardous material then it is sent to landfill. Waste recognized as recyclable is directed to the second checkpoint where a detailed inspection is performed. Processing begins only if the waste doesn't contain asbestos. Presorting is performed first and large items removed. Next, material with a maximum size of $350 \mathrm{~mm}$ is sent to the 'jaw crusher' machine and its size reduced to less than $120 \mathrm{~mm}$. Steel is then extracted by a magnetic separator and then a screen machine sifts C\&D material according to size. Material between 0 and $50 \mathrm{~mm}$ is directed to a machine that sifts into the three groups of $0-5 \mathrm{~mm}, 5-14 \mathrm{~mm}$, and $14-50 \mathrm{~mm}$. Material sifted is stored before being sold. Material of 50 to $75 \mathrm{~mm}$, and $75 \mathrm{~mm}$ and above is sent to two separate sorting chambers where waste that cannot be converted into aggregate is removed. After that, a final size reduction is performed by impact crusher and the remainder of the steel is sorted. Finally, the sifting machine sorts material into their three sizes of $0-10 \mathrm{~mm}, 10-40 \mathrm{~mm}$, and $40-75 \mathrm{~mm}$ that are finally sent to the sales department [22]. 


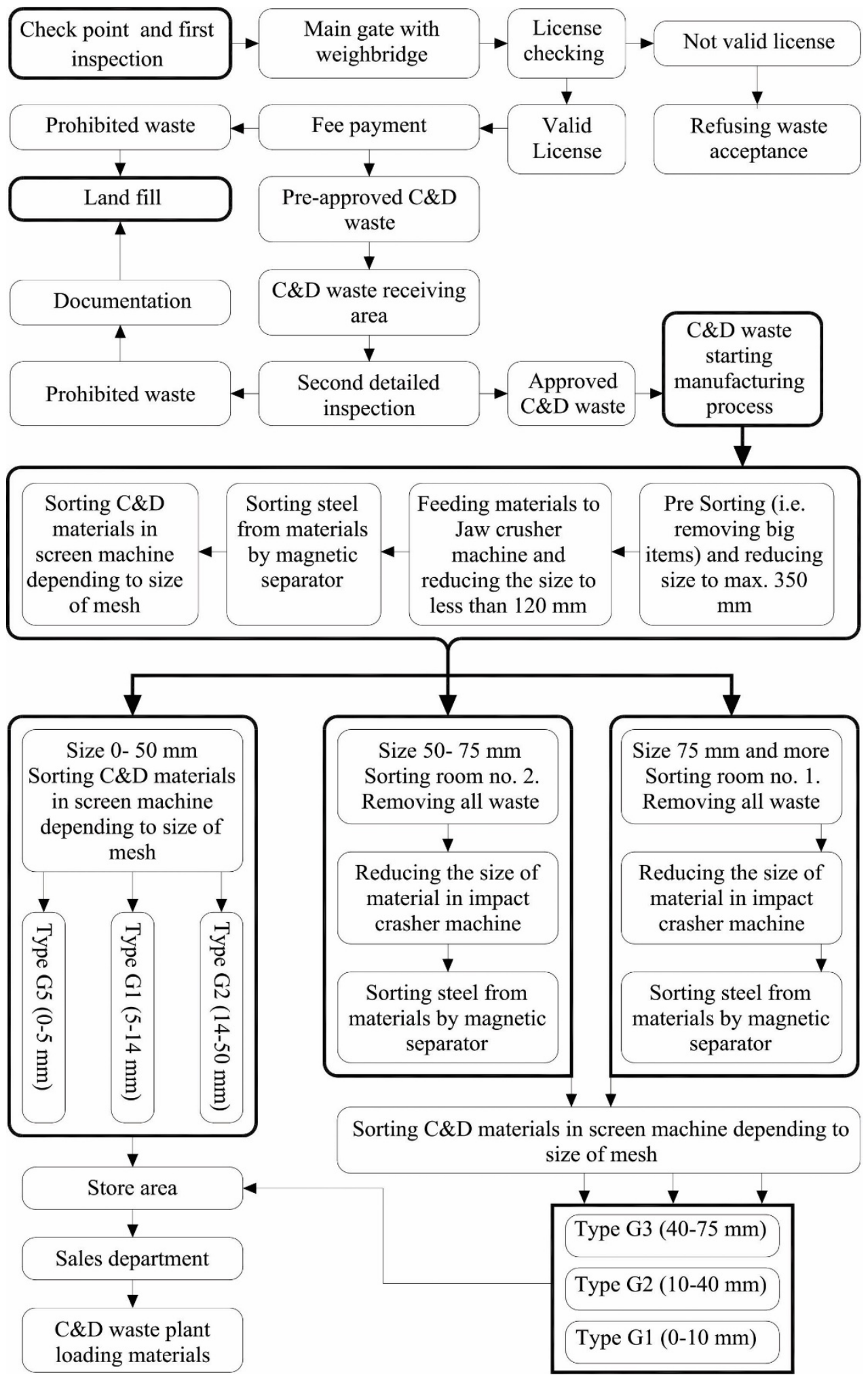

Fig. 1. The diagram of the C\&D waste Quality Assurance Procedure used in Bee'ah. [22] 
Manufactured Recycled Crushed Aggregate (RCA) consists of clean, hard, durable, angular fragments of rock, concrete and sand fragments of uniform quality. The RCA produced from C\&D waste is delivered by Bee'ah in six sizes (Fig. 2) and is guaranteed by the Abu Dhabi Quality and Conformity Council, established by His Highness Sheikh Khalifa Bin Zayed Al Nahyan, President of the United Arab Emirates and ruler of Abu Dhabi, by a Certificate of Conformity. Moreover, it is authorized to hold the Abu Dhabi Government's Trustmark for Environmental Performance [23].

\begin{tabular}{|l|l|l|}
\hline \multicolumn{2}{|l|}{ Type of RCA by Bee'ah } \\
\hline $\begin{array}{l}\text { Grade 1: size 0 } \mathrm{mm}-10 \\
\mathrm{~mm}\end{array}$ & $\begin{array}{l}\text { Grade 2: size } 10 \mathrm{~mm}-40 \\
\mathrm{~mm}\end{array}$ & $\begin{array}{l}\text { Grade 3: size } 40 \mathrm{~mm}-85 \\
\mathrm{~mm}\end{array}$ \\
\hline & & \\
\hline & & \\
\hline & & \\
\hline $\begin{array}{l}\text { Grade } 1: \operatorname{size} 5 \mathrm{~mm}-14 \\
\text { mm }\end{array}$ & $\begin{array}{l}\text { Grade 2: size } 14 \mathrm{~mm}-50 \\
\text { mm }\end{array}$ & Grade 5: size $0 \mathrm{~mm}-5 \mathrm{~mm}$ \\
\hline & & \\
& & \\
\hline
\end{tabular}

Fig. 2. Recycled Crushed Aggregate (RCA) from C\&D waste by Bee'ah. [22]

The use of RCA products has many environmental benefits including limiting the consumption of natural resources and diverting C\&D waste from disposal to landfill [23]. Moreover, the price of materials produced from $C \& D$ waste is very attractive for investors. Based on studies done in Kuwait [16] "a required amount of recycled aggregate annually it's $5 \%$ for reinforced concrete work, $50 \%$ for plain concrete and $100 \%$ for road works and backfilling" and this suggests large savings for investors.

\section{Summary and conclusions}

This study compares different sustainable regulations including regulations in the UAE, with goals adopted by the United Nations in Agenda 2030 [2]. Various sources of C\&D waste have been surveyed and compared with literature findings. Recycling facilities and the recycling process have been also investigated using the emirate of Sharjah [22] as an example.

The conclusions are as follows:

1. The sustainability of regulatory in the UAE, including C\&D waste management, have improved since the previous research conducted in 2010 [12]. The only existing sustainable regulations are established in the emirates of Abu Dhabi and Dubai even though Dubai regulations need improvement in two sectors pointed out in Table 2. The 
other five emirates lack clear and easily accessible public regulations to control C\&D waste management.

2. The main source of the C\&D waste seen in the presented case studies from Sharjah is caused by a lack of environmental awareness and professional training of staff. This confirms the results of studies conducted in Abu Dhabi and Dubai [12].

3. The current implementation of C\&D waste management is the weakest point in the chain of regulatory - practice - recycling.

4. Recycling facilities are there and ready to process large amounts of C\&D waste. However, the contractors' and workers' awareness of ecological and financial benefits that come from recycling is what needs to be improved.

The following actions are recommended:

1. Clear and easily accessible public regulations created by emirates of Sharjah, Ajman, Ras Al-Khaimah, Fujairah, and Umm al-Quwain. These regulations should consider sustainable goals.

2. Governmental bodies should encourage investors, consultants, and contractors to prevent and reduce $C \& D$ waste by commencing a program promoting awareness of the ecological and financial benefits that result from recycling.

3. More C\&D waste studies should be conducted to support amending local regulations to current implementation practices.

4. More studies and testing should be undertaken to produce new materials from recycled $\mathrm{C} \& \mathrm{D}$ waste.

In summary, regulatory and recycling facilities in the UAE have improved although particular areas still need addressing. Moreover, as observed and proven, significant improvements in implementation are needed.

\section{References}

1. UN, Report of the World Commission on Environment and Development, Our Common Future (1987)

2. UN, Resolution adopted by the General Assembly on 25 September 2015, Transforming our world: the 2030 Agenda for Sustainable Development (2015)

3. Official J. of the EU, Regulation (EU) No 305/2011 of the European Parliament and of the Council of 9 March 2011 laying down harmonised conditions for the marketing of construction products, L 88/5, (2011)

4. Official J. of the EU, Directive 2008/98/EC of the European Parliament and of the Council of 19 November 2008 on waste, L 312/3 (2008)

5. BRE Global, BREEAM International New Construction 2016, SD233, 1.0 (2016)

6. USGBC, LEED v4 Building Design and Construction (2016)

7. Department of Municipal Affairs, Abu Dhabi, The Pearl Rating System for Estidama, Building Rating System: Design \& Construction (2010)

8. Dubai Municipality, Dubai Electricity \& Water Authority, Green Building Regulations and Specifications in the Emirate of Dubai (2011)

9. M. Yeheyis, K. Hewage, M. Shahria Alam, C. Eskicioglu, R. Sadiq, Clean Techn. and Env. Policy, 15(1), 81-91 (2013)

10. A. Dania, J. Kehinde, K. Bala, Proceedings of the 3rd Scottish Conference for Postgraduate Research of the Built and Natural Environment, 121-129 (Glasgow, 2007)

11. L. Ekanayake, G. Ofori, Proceedings: Strategies for a Sustainable Built Environment, (Pretoria, 2000)

12. A. Al-Hajj, K. Hamani, Arch. Eng. and Des. Man., 7.4, 221-235 (2011)

13. B. A. G. Bossink, H. J. H. Brouwers, J. of Con. Eng. and Man., 122(1), 55-60 (1996) 
14. R. M. Gavilan, L. E. Bernold, J. of Con. Eng. and Man., 120(3), 536-552 (1994)

15. H. Lingard, P. Graham, G. Smithers, Cons. Man. and Ec., 18(4), 383-393 (2000)

16. N. Kartam, N. Al-Mutairi, I. Al-Ghusain, J. Al-Humoud, Waste Man., Department of Construction Engineering, Kuwait University, 24, 1049-1059 (2004)

17. U.S. Department of Energy, Greening Fed. Facil., An Energy, Environmental, and Economic Resource Guide for Federal Facility Managers and Designers, 2nd ed, 170$171(2001)$

18. G. A. Bekr, J. of Con. Eng., 2014, Art. ID 283298 (2014)

19. United Arab Emirates Data Portal. Socio-Economic Data. Collected waste. http://bayanat.ae/vndyxhe/education-statistic (retrieved: 05.11.2016)

20. Tadweer The center of Waste Management - Abu Dhabi, http://www.cwm.ae/ (retrieved: 15.11.2016)

21. A. A. Saifaie, Envirocities eMagazine, 4, 4-7 (2013)

22. Sharjah Environment Company (Bee'ah) http://beeah.ae/ (retrieved: 15.11.2016)

23. Abu Dhabi Quality and Conformity Council, Abu Dhabi Certification Scheme for Recycled Crushed Aggregate. Issue 1.0 (2013) 